\title{
Study on Facility Development of Maccini Baji Port as a Minor and Hub Port for Small Island Connectivity
}

\author{
Akbar $^{\text {a }}$, Misliah ${ }^{\mathrm{b}}$, Andi Siti Chairunnisa ${ }^{\mathrm{c}}$, Suandar Baso ${ }^{\mathrm{d}, *}$

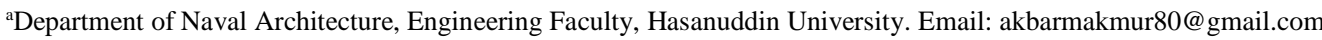 \\ bepartment of Naval Architecture, Engineering Faculty, Hasanuddin University. Email: misliahidrus@ yahoo.co.id \\ 'Department of Naval Architecture, Engineering Faculty, Hasanuddin University. Email: andi.chairunnisa@yahoo.co.id \\ ${ }^{\mathrm{d}}$ Department of Naval Architecture, Engineering Faculty, Hasanuddin University. Email: s.baso@eng.unhas.ac.id
}

\begin{abstract}
Maccini Baji port as minor port is a hub of small islands connectivities in Pangkejene and Kepulauan Regency, South Sulawesi. It has strategic role to serve cargo and passenger ship from not only small islands in Pangkejene and Kepulauan Regency but also from outside such as Papua, Maluku, and Nusa Tenggara Timur. Correspondingly, Maccini Baji port has faced the fluctuated increase of visited ships from 2011 to 2018 based on forecasting result by using stepwise and regression methods and has a good potential to be developed especially for cement cargo. This study describes analysis on port facility performance of Maccini Baji and its development. The research result has shown the berth occupancy ratio (BOR) of Maccini Baji port in 2022 will reach $61 \%$. This has become a primarily point to consider in lengthening berth of Maccini Baji port. Therefore, the port berth of Maccini Baji should be lengthened 272 meters where existing berth length is 225 meters. In addition, basin and anchorage area will be also developed where the dimensions of turning basin will be 6 meters in depth, 121.8 meters in diameters, and its area will be $116 \mathrm{~m}^{2}$. The dimensions of anchorage area will be 6 metres in depth, and 105.9 meters in radius and its area will be $35.21 \mathrm{~m}^{2}$. Based on SWOT analysis, some aspects will be considered to succesfully develop Maccini Baji port such as geographic location, port facility improvement, increas of service capacity and facility efficiency, development of hinterland area, local government participation.
\end{abstract}

Keywords: Maccini Baji port; minor port; port development; port facility; small island connectivity

\section{Introduction}

The port is a node of the sea-to-land transportation system which is an economic unit whose role is to stimulate the growth and development of trade or the economy consisting of storage, distribution, processing, marketing, and others. Inland waterways and maritime transport network consist of two equally important elements i.e. links and nodes. For an efficient and reliable functioning of the transport network both elements must be equally developed and harmonized [1]. Correspondingly, port has a strategic role in enhancing the resources distribution and the port role today exceeds the simple function of services to ships and cargo. Apart from their role as the traditional sea, ports are a good location for value-added logistics but also for other related services including industrial, trade, financial, and even leisure and property development activities. Thus, the port system not only serves as an integral component of the transport system, but also is a major sub-system of the broader production, trade and logistics systems [2].

${ }^{*}$ Corresponding author. Tel.: +62 85255625397

Jl. Poros Malino, Borongloe, Bontomarannu, Kabupaten Gowa, Sulawesi Selatan 921119
The enhancements or developments of ports have been done significantly and their required in-depth studies. Palmer investigated the main current trends affecting seaport development [3]. Similarly, several studies of port development have been done such investigation seaports, dry ports, and development corridors and its implication for regional development in India [4]. Dwarakisha and Salim studied the role of ports in the development of a nation [5]. Balasubramanian investigated the adverse effects of port development on coastal ecology and community in Ennore [6].

Regardless, the development of small size ports should be considered because a number of small size of ports in developing country are big and nowadays its function has a big essential and important. However, there are often thought to be playing a secondary part where their logistics and socio-economic role are still largely undefined and underestimated in literature and in policies. Moreover, their visibility is limited and their voice often weak [7]. Kuntoji G. and Rao S. has been reviewed the development of minor ports to improve the economy of developing country [8]. Based on these dicussion above, the development of small sized port is rarely discussed and 
studied. Therefore, the study regarding the development of small sized port is widely needed to make more intrepretations.

In present study describes the development of Maccini Baji port where the port's facilities are in extremely poor condition and capacity limitations. Despite having poor conditions, the calling ships in Maccini Baji port are increasing in 2011 to 2018. By those reasons, Maccini Baji port has been improved its operations as a minor port and hub for small island connectivity by lengthening its berth port due to over berth occupancy.

One of small sized ports in South Sulawesi is Maccini Baji port which is located in Pangkajene and Kepulauan Regency with latitude longitude coordinates $4^{\circ} 46^{\prime}$ and $119^{\circ} 29^{\prime}$. The location of Maccini Baji port is shown in Fig. 1. Based on the minister of transportation's decree No. KP 432/2017, the hierarchy of Maccini Baji port is set as a local feeder port.

\section{Research Methodology}

The present study discusses the facility development of a minor and hub port for small island connectivity. Here, the case study was addressed to Maccini Baji port. In order to obtain research results, several methods and steph have been systematically done as discussed below.

\subsection{Data collection}

Some data were collected and observed related with the development of Maccini Baji port (Fig. 1) such as socio demography, economic, hinterland, population, Gross Regional Domestic Product (GRDP), and land-use planning and others in Pangkejene and Kepulauan Regency. The data of trip generation were observed including ship type, people and cargo movement. Moreover, land transportation network, facilties and operation service of Maccini Baji port were observed as well.

\subsection{Analysis step}

The number of calling ships in Maccini Baji port was predicted and projected by using linear regression and

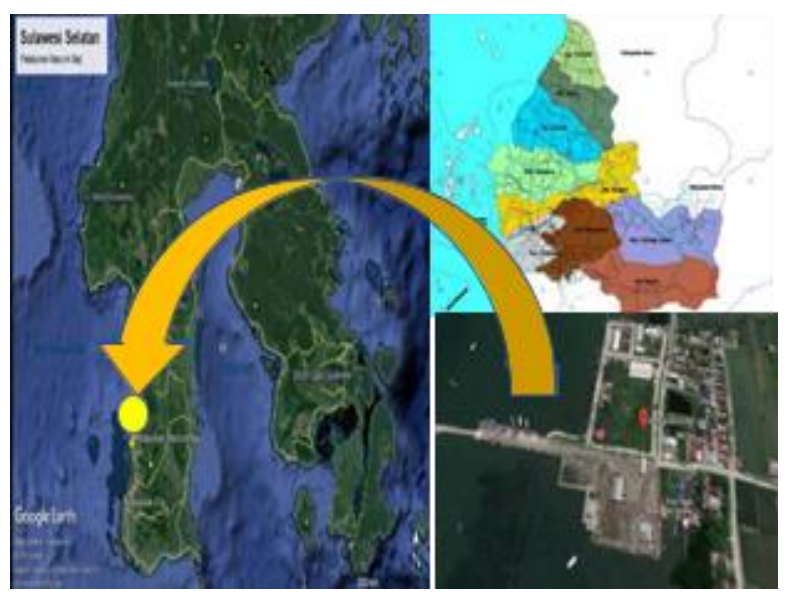

Figure 1. The map of Maccini Baji port location in Pangkejene and Kepulauan Regency stepwise models. This was investigated from 2011 to 2018 by using linear regresion model to show a tendency of the number calling ship in icreasing year. Furthermore, this was projected by using stepwise model from 2011 to 2034 taking into account population and GRDP. Here, linear regression and exponential growth were used also to compare their results based on the coefficient of determination ( $\mathrm{R}$ squared).

Given data set of $n$ statistical units, a linear regression model assumes that the relationship between the dependent variable and the independent variable. The model has the form as follow:

$$
Y=a+b X
$$

where $Y$ is the dependent variable, $X$ is the independent variable, $b$ is the slope of the line (coefficient) and $a$ is the $Y$-intercept (coefficient). Correspondingly, the utilization of port facility in Maccini Baji port was assessed using Berth Occupancy Ratio (BOR) formula to achieve reguired standardized level and optimum throughput related with available data and forecasting results. Then, the assessment result was verified by using port performance indicator of UNCTAD requirement. The berth port length was simulated by using some assumptions based on ship dimension and space need between ship related with forecasting results. Berth occupancy ratio shows the port service level which can be defined generally as given:

$$
\begin{aligned}
& \mathrm{BOR}=\left(T_{0} / T_{t}\right) \times 100 \% \\
& \mathrm{BOR}=\left(n_{s} \times L s+10 \times n_{t}\right) /\left(L_{b} \times 24 \times d\right) \times 100 \% .
\end{aligned}
$$

where, $T_{0}$ is total time which quay wall is occupied from berthing to un-berthing (vessel turnaround time) in the proposed time span. $T_{t}$ is total time which quay wall is able to service in the proposed time span (working times). Moreover, $n_{s}$ is a number of ships

Port facilities that are needed have been analyzed based on berth port, fairway/channel etc. The berth length is determined based on IMO regulation as given by:

$$
L_{p}=L_{o a}(n+1)+10 \% L_{o}
$$

where $L_{p}$ is jetty length, $L_{o a}$ is length overall of a ship, and $n$ is a number of ships.

A number of ships that are moored in jetty could be calculated by using formula as follow:

$$
A=(C s \times B T) /(O T \times \mathrm{BOR})
$$

where $C s$ is ship number for service (ship/year), $B T$ is berthing time (hour/ship), BOR is berth occupancy ratio (Eq. 2), and $O T$ is port operation time per year (hour).

\subsection{Strategy for port development}

In order to evaluate and develop Maccini Baji port, a strategy planning was made by using Strenghts, 
weaknesses, opportunities, and threats (SWOT) analysis. The internal and external factors that affect on Maccini Baji port were identified and assessed. Then, Maccini Baji port was determined its position and competition in creating a port strategic framework. The SWOT analysis is a square with each of the four areas making up one quadrant (I, II, III, and IV).

\section{Results and Discussions}

\subsection{Existing facilities in Maccini Baji port}

Table 1 shows the main facilities in Maccini Baji port. Recently, Maccini Baji port has no equipment to support loading-unloading activity from and/to dock, therefore, loading/unloading is still handled by human.

Nowadays, Maccini Baji port serves pioneer sea transportation which is organized by the Indonesia Government in providing operating subsidies to the pioneer fleet. The pioneer Papua Dua serves routes namely Liukang Tangayya between Balo-Baloang Island, Matalaang Island, Sapuka Island, and Sailus Island and Badas port in Nusa Tenggara Barat. On the other hand, sail-boat machine (Pelra) dominantly transport cement to Kaimantan Island. A number trip per year is 21 to 26 times and requires operation time 11 to 14 days.

Correspondingly, Maccini Baji port also has a mooring facility for wooden boats that serve transportation between islands araound Liukang Tupabbiring Utara. Table 2 shows calling ships from 2011 to 2018 which almost increased per year. However, it decreased in 2013 and 2016 and significantly increased in 2014, 2015, and 2018.

Table 1. Main facilities in Maccini Baji port

\begin{tabular}{|c|c|}
\hline Type of Facility & Description \\
\hline \multicolumn{2}{|l|}{ Dock } \\
\hline -Concrete dock & Length $=225 \mathrm{~mm}$, width $=8 \mathrm{~mm}$ \\
\hline -Passenger Pontoon Pier & Length $=20 \mathrm{~mm}$, width $=10 \mathrm{~mm}$ \\
\hline Concrete Pier Trestle & Length $=250 \mathrm{~mm}$, width $=6 \mathrm{~mm}$ \\
\hline Gangway Terminal & Length $=125 \mathrm{~mm}$, width $=4 \mathrm{~mm}$ \\
\hline \multicolumn{2}{|l|}{ Passenger } \\
\hline Causeway & Length $=190 \mathrm{~mm}$, width $=6 \mathrm{~mm}$ \\
\hline Warehouse of & Total $=3$ units, area $=400 \mathrm{~m}^{2}$ \\
\hline \multicolumn{2}{|l|}{ Deviations } \\
\hline Stacking Field & Area $=253 \mathrm{~m}^{2}$ \\
\hline Passenger Terminal & Amount $=1$ Unit, Area $=300 \mathrm{~m}^{2}$ \\
\hline Fire Fighting Facilities & Amount $=1$ Unit, Area $=100 \mathrm{~m}^{2}$ \\
\hline Equipment Maintenance & Amount $=1$ Unit, Area $=200 \mathrm{~m}^{2}$ \\
\hline Facilities & \\
\hline
\end{tabular}

Table 2. The calling ship number per year in Maccini Baji port

\begin{tabular}{lc}
\hline Year & Calling ship (set) \\
\hline 2011 & 332 \\
2012 & 362 \\
2013 & 343 \\
2014 & 443 \\
2015 & 599 \\
2016 & 548 \\
2017 & 580 \\
2018 & 650 \\
\hline
\end{tabular}

\subsection{The performance of Maccini Baji port}

Here, the performance of Maccini Baji port was analized taking into account the utiliztion of berth port, basin and anchorage area.

BOR of Maccini Baji port was analyzed based on ralated data, forecasting result of calling ship, and dock usage rate in evary year. In 2019, the berth lenght of Maccini Baji port is 225 meters and it could moore four ships in assuming 40.6 meters ship length, berthing time (BT) 24 hours, and 10 meters for space between ship. Referring to those assumptions, BOR was obtained 50\% and this shows that BOR is still not optimum.

Meanwhile, the BOR of Maccini Baji port from 2019 to 2021 will reach $61 \%$ with four moored ships and space between ship as assumed similar with previous assumptions. This BOR shows higher magnitude than BOR standard given by UNCTAD requirement. This means that berth condition will be utilized fully and this will also affect on queue for other ships in case there is not berth development. For this reason, the berth port must be lenghtened.

Correspondingly, the forecasting of calling ship will increase from 2018 to 2034 and it will affect on berth utilization. However, BOR of Maccini Baji port will reach $61 \%$ in 2022, therefore, the berth of Maccini Baji port must be lengthened. As known, the existing berth lenght of Maccini Baji port is $225 \mathrm{~m}$ and it will be then lenghtened becoming $272 \mathrm{~m}$ or additing length $47 \mathrm{~m}$ to meet its BOR. In addition, the berth length in $272 \mathrm{~m}$ will also cover until 2034.

Moreover, other port facities were analized their utilization such as turning basin and anchorage area as well. Regarding to berth development, the basin and anchorage area will be developed as well. Therefore, the dimensions of turning basin will be 6 meters in depth, 121.8 meters in diameters, and its area will be $116 \mathrm{~m} 2$. In additions, the dimensions of anchorage area will be 6 metres in depth, and 105.9 meters in radius and its area will be $35.21 \mathrm{~m} 2$.

\subsection{Strategy for the development of Maccini Baji port}

In order to develop Maccini Baji port, the internal and external factors that effect on its port perfomance were indentified firstly as shown in Table 3 and 4 . Then, the weight, rating, and score each element of internal and external factors was determined and obtained by questionnarie.

As explained on section methodology, the analysis that used in determinating the development of Maccini Baji port is SWOT method. Table 3 and 4 show the weight, rating, and score for each internal factor and external factor. The score of strength factor in internal factors shows higher comparing with weakness factor and this means that the internal factor has a sufficient strong or good potential for developing Maccini Baji port. The avergared total score of internal factors is 2.43 . 
Table 3. SWOT Matrix for the internal factors of Maccini Baji port

\begin{tabular}{|c|c|c|c|}
\hline Internal Factors & Weight & Rating & Score \\
\hline \multicolumn{4}{|l|}{ Strength } \\
\hline $\begin{array}{l}\text { 1.Increasing the number of } \\
\text { calling ship }\end{array}$ & 1 & 3 & 3 \\
\hline $\begin{array}{l}\text { 2. Good strategic location as a } \\
\text { hub for small island }\end{array}$ & 1 & 4 & 4 \\
\hline \multirow[t]{2}{*}{$\begin{array}{l}\text { 3. Having regional area } \\
\text { development }\end{array}$} & 1 & 2 & 2 \\
\hline & & Subtotal & 9 \\
\hline \multicolumn{4}{|l|}{ Weakness } \\
\hline $\begin{array}{l}\text { 1.Poor loading and unloading } \\
\text { equipments }\end{array}$ & 0 & 2 & 0 \\
\hline $\begin{array}{l}\text { 2.Limited depth basin and } \\
\text { anchorage area }\end{array}$ & 1 & 3 & 3 \\
\hline 3.Less people mobility & 1 & 2 & 2 \\
\hline \multirow[t]{2}{*}{$\begin{array}{l}\text { 4. High cost and time for port } \\
\text { development }\end{array}$} & 1 & 3 & 3 \\
\hline & & Subtotal & 8 \\
\hline Total Score & & & 17 \\
\hline Average & & & 2.43 \\
\hline
\end{tabular}

Table 4. SWOT Matrix for the enternal factors of Maccini Baji port

\begin{tabular}{lccc}
\hline \multicolumn{1}{c}{ External Factors } & Weight & Rating & Score \\
\hline $\begin{array}{l}\text { Opportunity } \\
\begin{array}{l}\text { 1. Having market share potential } \\
\text { as a hub small islands }\end{array}\end{array}$ & 1 & 4 & 4 \\
$\begin{array}{l}\text { 2. Goverment supporting for } \\
\text { development }\end{array}$ & 1 & 2 & 2 \\
$\begin{array}{l}\text { 3. Having big population in } \\
\text { island cluster, Pangket } \\
\text { Regency }\end{array}$ & 1 & 4 & 4 \\
\hline $\begin{array}{l}\text { Threat } \\
\begin{array}{l}\text { 1. Advance technology } \\
\text { development without high } \\
\text { level of aexpertise }\end{array}\end{array}$ & 0.5 & 2 & 1 \\
$\begin{array}{l}\text { 2. Regulation for serving large } \\
\text { ship size }\end{array}$ & 1 & 3 & 3 \\
\hline \multicolumn{2}{c}{ Average } & Subtotal & 10 \\
\hline
\end{tabular}

On the other hand, the score of oppurtunity factor in external factor is higher also comparing with threat factor and this means that the oppurtunity of Maccini Baji port could minimize the threat which is faced now and next future. This situation has become proper for developing Maccini Baji port. The averaged total score of external factors is 2.80 .

The position of internal and external factors in SWOT matrix for Maccini Baji port is in quadrant I where the opportunity and strenght factors are dominant. Therefore, Maccini Baji port could be developed for anticipating the increase of the calling ship in the future.

Maccini Baji port is experiencing significantly the increase of calling ship number, as well as it has a startegitc location as a hub for small islands. This has a potential of market share, regional area development, and government support.

The above discussion highlighted that the development of Maccini Baji port will be focused on service of loadingunloading activities and port facilities. This development is also as overhead capital to improve transportation service, economy production and distribution. Correspondingly, the followings are some aspects that will be considered in development startegy:

1. The geographic location of the ports is logistically most favorable.

2. Taking advantage of existing facilities and improving facility.

3. Increasing the capacity of service and facility efficiency.

4. Development of hinterland area.

5. Participating local government in developing Maccini Baji port.

\section{Conclusions}

Currently, the calling ships in Maccini Baji port was increasing significantly from 2011 to 2019 and this will affect that BOR of Maccini Baji port will reach $61 \%$ in 2022, however the existing facilities of Maccini Baji port are in extremely poor condition and capacity limitations. The study on the facility development of a minor port which is addressed to Maccini Baji port was successfully done.

Several main points will be concerned to develop Maccini Baji port as follows:

a. The berth will be lenghtened becoming $272 \mathrm{~m}$ or additing length $47 \mathrm{~m}$ from existing lenght to meet its increased BOR.

b. The basin and anchorage area will be also developed where the dimensions of turning basin will be 6 meters in depth, 121.8 meters in diameters, and its area will be $116 \mathrm{~m} 2$. The dimensions of anchorage area will be 6 metres in depth, and 105.9 meters in radius and its area will be $35.21 \mathrm{~m} 2$.

c. Based on SWOT analysis, some aspects will be considered to succesfully develop Maccini Baji port such as geographic location, port facility improvement, increas of service capacity and facility efficiency, development of hinterland area, local government participation.

\section{References}

[1] S. Jovanovic et al., "Port Infrastructure and Industrial Development: Status of Port Infrastructure Development along the Danube," 2017.

[2] UNCTAD, "Assessment of a Seaport Land Interface: An Analytical Framework," 2004.

[3] S. Palmer, "Current Port Trends in an Historical Perspective," J. Marit. Res., pp. 99-111, 1999.

[4] A. H. Kidwai and G. Kuzur, "Seaports, Dry Ports and Development Corridors: Implication for Regional Development in Globalising India," 2015.

[5] G. S. Dwarakisha and A. M. Salim, "Review on the Role of Ports in the Development of a Nation," in International Conference on Water Resources, Coastal and Ocean Engineering, Aquatic Procedia 4, 2015, pp. 295-301.

[6] B. Balasubramanian, "Challenges Towards Sustainable Port Development in India: The Adverse Effects of Port Development on Coastal Ecology and Community in Ennore, a case study," 2018. 
[7] M. Simona, "A Cluster Initiative: Small and Medium Sized Ports as Hubs for Smart Growth and Sustainable Connectivity," Interreg IVA 2 Seas Programme, 2 Seas Magazine, 2014.
[8] G. Kuntoji and S. Rao, "A Review on Development of Minor Ports to Improve the Economy of Developing Country," in International Conference on Water Resources, Coastal and Ocean Engineering Aquatic Procedia 4, 2015, pp. 256-263. 